\title{
THE UNCREATED DESTINATION OF CREATED ICON: SAINT MAXIMUS THE CONFESSOR
}

\author{
Vukašin MILIĆEVIĆ*
}

\begin{abstract}
Creating man according to his image and likeness, God gave him a goal to achieve, and ordered everything so that man can get it. The God-given goal of man's existence is the union with his Creator. The capability to achieve that union is the one and only content of the image of God in man. Therefore, we see that man's existence is set up in a dialectical frame of created and uncreated realities. Since both the beginning and the goal of human existence belong to the domain of uncreated, the question that I would like to ask and try to resolve, starting from ideas given by St. Maximus the Confessor, especially in his Amb. 10 , is how to understand createdness of man, that created and living image of the uncreated God?
\end{abstract}

Key words: image and likeness, St Maximus the Confessor, created, uncreated, Melchizedek, passivity.

\section{Introduction}

In this paper, I would like to pay attention to a very characteristic contextualization of a theo-anthropological concept of the image of God. Specifically, I have in mind an important section of the St Maximus the Confessor's Ambigua 10 that comprises a series of five relatively short chapters that are exposing a mystical contemplation concerning Melchizedek. Since I believe that the text itself is, due to its explicity, extremely important, I will allow myself to quote it directly to a large extent.

Firstly, it should be noted that in this text we are facing a substantially Christological understanding of the concepts of the divine 
image and likeness. This is by no means surprising; there is a consensus among Maximian scholars that his thought is absolutely Christocentric, based on the characteristic and al- embracing concept of the Mystery of Christ ${ }^{1}$.

However, I believe that there is a need for further research and, to a certain extent, reinterpretation of views generally accepted. I will specifically point out a few problems that I consider in this respect as important, and for whose eventual solution the text we are dealing with may be an important element. First of all, in view of such a characteristic understanding of the Mystery of Christ as exposed in this text, how do we understand the fundamental distinction on which is based not only his, but every Orthodox theo-ontological system, namely, the distinction between uncreated and created? Is it possible to speak about the Mystery of Christ as created or uncreated reality, and in what sense? What will be left of createdness of God's creature when this Mystery achieves its fullness?

The answer to these questions is a prerequisite for answering the fundamental question of anthropology, namely, what is man? It is clear that within the frame of Christian anthropology it is not possible to answer this question by treating it apart from man's relation to the Mystery of Christ. Namely, there is no such thing as man per se; or, to put it another way, man per se is the man in Christ, or, more directly, Christ himself.

\section{The text}

The Ambigua 10 is a large series of contemplations inspired by a sentence from the sermon of St. Gregory the Theologian spoken out in honor of St. Athanasius the Great:

If therefore it happens ${ }^{2}$ to anyone that, passing by means of reason and contemplation through matter and the fleshly, whether called cloud or veil, to become assimilated to God and united to the most pure light, so

${ }^{1}$ Cf. Ad. Thal. 60, PG 90, 620CD.

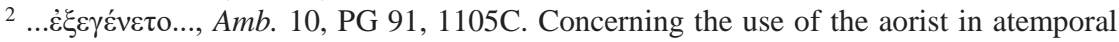
meaning in Greek theological texts, the note given by Paul Plass in his text on the concept of transcendent time at St Maximus might be more than interesting, v. Paul Plass, "Transcendent Time in Maximus the Confessor", in The Thomist, no.2/1980, p. 272. 
far as is permitted to human nature, this person is blessed by his ascent from here and his deification there, which is granted to those who genuinely live the philosophical life and transcend the material dyad through the unity the mind perceives in the Trinity ${ }^{3}$.

Starting from these words, Maximus begins a debate with those who, we may assume, by referring to them, were arguing that philosophy according to God, and that one is the road that leads to deification, is not the practical one, but only speculative, i.e. theoretical ${ }^{4}$. Initially, therefore, Maximus's intention is to expose assumed practical (i.e. ascetical) meaning of St. Gregory's words. Therefore, the principal problem of this longest Ambigua is aretological ${ }^{5}$; but the broader frame of aretology, understood in this way, is a more comprehensive problem of the knowledge of God. Further, since both gnoseology and aretology in Maximus's theological system are directly based on the fundamental concept of the union of God and man, they are both in function of man's deification $^{6}$, it is natural that this long ambigua sums up in a very precise

${ }^{3}$ Amb. 10, PG 91, 1105CD; English translation to which I will refer in: Andrew LouTH, Maximus the Confessor, London and New York, Universiy of Durham, Routledge, 1999, p. 95. On a relation between Maximus's interpretation and the original text of the sermon, see: Григорий В. БенЕвич, “Логос Мелхиседека. Экзегеза и парадигма обожения у прп. Максима Исповедника”, Вестник по.1/2011, p. 191.

${ }^{4}$ On the opponents of St Maximus and the question of his complex relation with origenistic tradiotions, see: Polycarp SHERWOOD, The Earlier Ambigua of S. Maximus the Confessor and his Refutation of Origenism, Studia Anselmiana XXXVI, Roma, 1955; Polycarp Sherwood, "Maximus and Origenism. APXH KAI TE $\Lambda \mathrm{O} \Sigma "$ ", Berichte zum XI. Internationalen Byzantinisten-Kongress, Munchen, 1958, Korreferate zu III, 1, Miinchen, Beck, 1958, p. 1-26; Г. И. БЕнЕВич, „Об оппонентах преп. Максима в Трудностях к Иоанну (дополнение к исследованию Поликарпа Шервуда): Не только оригенизм", in: ур. Г. И. БЕнЕвич, Преподобный Максим Исповедник: Полемика с оригенизмом и моноэнергизмом, Санкт Петербург, Издательство Олега Абышко, 2014, p. 593-613; Maximos Constas, St. Maximos the Confessor: The Ambigua to John: Introduction to Ambiguum 10 (https://www.academia.edu /11023287/ Introduction_to_Maximos_the_Confessor_Ambigua_10.1-27 (accessed: April 29, 2017).

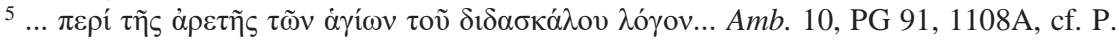
SHERWOOD, The Earlier Ambigua, 33-34, who identifies as the central motif of passing

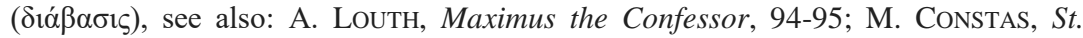
Maximos.

${ }^{6}$ Cf. Amb. 10, PG 91,1108B. 
and direct way all the most important aspects of his theological system and treats fundamental questions of ontology and cosmology.

St Maximus comes to Melchizedek by pointing out the examples of those who, by leading a God knowing life, have overcome dyad and reached unity that is contemplated in the Trinity, that is, we may say, the examples of those deified. It may be striking that here Maximus almost exclusively points to the personalities from the Old Testament. However, we will see that the most special place in this way, but not only with regard to the Old Testament only, belongs to the Melchizedek ${ }^{7}$.

Namely, in the chapters following the contemplation of Melchizedek, Maximus gives similar contemplations of Abraham and Moses $^{8}$. Explaining the ways of how these saints who lived before and at the time of the Law were living their lives in accordance with God, Maximus says that the example which we have to follow, and that is the example of Christ, can be contemplated threw their lives typologically ${ }^{9}$. Here, we may recall the words of the Apostle who says that all this happened to them as an example, and that all these things were written down for our instruction (1. Cor. 10:11). However, starting from this general biblical and patristic understanding of typology, we cannot understand what Maximus says about Melchizedek, because his participation in the divine reality is of the one who shares directly:

...the one who discerns with sagacity how he ought to love God, the transcendent nature, that is beyond reason and knowledge and any kind of relationship whatever, passes without relation ${ }^{10}$ through everything

7 G. Benevich makes very important remarks regarding a broader historical and theological context of this striking use of the Old Testament figures as models for the ascetical life, especially regarding Melchizedek as the paradigm of deification, as it is the case in the text that we are dealing with. He notes that this insisting on the Old Testament personalities is certainly not result of a chance, but that it represents a theological attitude, namely: “...that it testifies that St Gregory and, in accordance with him, St Maximus understand the Old Testament saints as equal to those after Christ regarding their sublimity in the knowledge of God (let us remind ourselves that Or. 21 is a word of praise in honor of St Athanasius the Great who is being compared therefore with the great saints of the Old Testament in terms of spiritual growth), see: $Г$. В. БЕНЕВИч, Логос Мелхиседека, p. 191.

${ }^{8}$ Amb. 10, PG 91, 1145C-1149C; A. LouTh, Maximus the Confessor, p. 117-119.

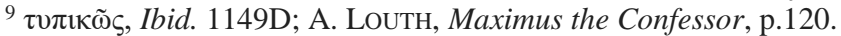

${ }^{10} \dot{\alpha} \sigma \chi \varepsilon \dot{\tau} \tau \omega \varsigma$, Amb. 10, PG 91, 1153BC; A. Louth, Maximus the Confessor, p. 121-122. 
sensible and intelligible and all time and eternity and space. Finally, he is super-naturally stripped bare of every energy that operates in accordance with sense or reason or mind, and ineffably and unknowably attains the divine delight that is beyond reason and mind, in the form and fashion that God who gives such grace knows and those who are worthy of receiving this from God understand. He no longer bears about with him anything natural or written, since everything that he could read or know is now utterly transcendent and wrapped in silence ${ }^{11}$.

For St. Maximus, Melchizedek is the one who is more than all the others made worthy to become an image of Christ. In fact,

...this great Melchisedec because of the divine virtue created in him is worthy to be an image of Christ the God, and of his ineffable mysteries, to whom all the saints are gathered together as to an archetype and source of the good impression that is in each one of them, especially this one, as bearing in himself for all the others most of the patterns of Christ ${ }^{12}$.

The way in which St. Maximus describes Melchizedek's participation in Christ makes it impossible to point out any difference in this respect between the Old and New Testaments. All features that Melchizedek, made worthy to be above the time and the nature, made similar to the Son of God, acquires by the grace are actually properties of the incarnated Son of God. However, it is crucial for us to understand that this directly implies the overcoming of those properties by which God's creature is substantially defined, i.e:

... by the the very highest pitch of grace in accordance with virtue, he has perfectly put off natural characteristics. And when it is said that he has neither beginning of days nor end of life, it bears witness to a knowledge embracing the properties of all time and eternity, and to a contemplation transcending existence of all material and immaterial being.

Thus, Melchizedek overcomes the limits of created nature by virtue, and the boundaries of time bound by perfect contemplation; virtue and contemplation are means by which divine likeness is being

11 Ibidem, $1153 \mathrm{C}$.

${ }^{12}$ Amb. 10, PG 91, 1141C; A. Louth, Maximus the Confessor, p. 115. 
revealed ${ }^{13}$ :

Thus the deliberation nobly struggles through the virtues against the law of nature, that is so difficult to fight against, and through knowledge the movement of the mind steps without defilement over properties of time and eternity. With these it is not right to regard as characteristic the property of what is abandoned, but rather the magnificence of what is assumed, from which and in which alone they are and are known ${ }^{14}$.

So, again, the idea of becoming similar to the Son and the Logos of God apart from the context of Christology, the context of the incarnation, would represent a serious inconsistency in Maximus' thought. However, it is clear that St. Maximus does not have in his mind such kind of divine likening; properties which are acquired by Melchizedek are not merely divine, but theandric, namely the characteristics embodied by incarnated Son of God.

However, what in this sense can be characterized as a curiosity, I repeat, is that this seems to be resulting in a complete assimilation into the divine reality. So Melchizedek, in a supernatural way by virtue and knowledge, freely, through the good choice of the dignity that is within his power ${ }^{15}$, overcame time and aion and was made similar to God, since he

...was begotten from God through the Word in the Spirit by grace, and bore in himself safe and true the likeness of God the begetter (since in the process of begetting what is begotten is naturally the same as the begetter, for it is said: what is begotten from flesh is flesh, and what is begotten from the Spirit is spirit (John 3:6)).

So, what we see here is the direct transition from Christological context to the sphere of, let us say so, pure theology. Therefore, Melchizedek will not be determined by

...natural and temporal properties, in which father and mother and genealogy, and beginning and end of days are included, which things having passed beyond he is completely released from them, that he is named but from divine and blessed characteristics, after which his form

${ }^{13}$ Cf. Ibid. 1140AB; A. Louth, Maximus the Confessor, p. 113.

${ }^{14}$ Amb. 10, PG 91, 1140BC; A. Louth, Maximus the Confessor, p. 113.

15 Ibidem, 1140C; A. Louth, Maximus the Confessor, p. 114. 
has been modelled, to which neither time, nor nature, nor reason, nor mind, nor anything else that can be circumscribed can attain. Therefore the great Melchisedec is recorded as being without father or mother or genealogy, having neither beginning of days nor end of life, as the true word of God-bearing men declares about him, not on account of a nature that is created and from nothing, in accordance with which he began to be and will cease to be, but on account of divine and uncreated grace, which eternally exists beyond every nature and all time, from God who eternally is, in accordance with which alone he is acknowledged as wholly begotten from the whole $[\mathrm{God}]^{16}$.

However, this transition from Christology to pure theology cannot be understood as if there is a point of discontinuity between these two realities. It seems as if Maximus is trying to make a kind of balance between these two realities by turning constantly to fundamentally Christological motifs. So, everything that is above nature and time, all that is effected by divine and uncreated grace, retains Christological meaning since it does not refer to a reality independent of the Incarnation and the history of salvation since

...this great Melchisedec because of the divine virtue created in him is worthy to be an image of Christ the God, and of his ineffable mysteries, to whom all the saints are gathered together as to an archetype and source of the good impression that is in each one of them, especially this one, as bearing in himself for all the others most of the patterns of Christ ${ }^{17}$.

Or, even more directly:

For our Lord and God, Jesus Christ, who is absolutely single, is in nature and truth without father and without mother and without genealogy, having neither beginning of days nor end of life. He is without mother because of the immaterial, bodiless and completely unknowable manner of his pre-eternal begetting from on high from the Father. He is without father according to his temporal and bodily begetting here below from his mother, which took place after a conception without intercourse. $\mathrm{He}$ is without genealogy, since both of his begettings have a form that is universally inaccessible and incomprehensible to all ${ }^{18}$.

${ }^{16}$ Amb. 10, PG 91, 1140D-1141B; A. LouTH, Maximus the Confessor, p.114

${ }^{17}$ Ibidem, 1141C; A. Louth, Maximus the Confessor, p. 115.

18 Ibidem, 1141D-1144A; A. LouTH, Maximus the Confessor, p. 115. 
Nevertheless, and here we come to the climax, such a full participation in the Mystery of Christ implies not only the perspective of infinity that is revealed in front of man's existence, but also, more importantly, the perspective of beginninglessness, since the deified man

...has no experience of what is present to it, and has become without beginning and end ${ }^{19}$; he no longer bears within himself temporal life and its motions, which has beginning and end and is disturbed by many passions, but he possesses the sole divine and eternal life of the indwelling Word, a life unbounded by death ${ }^{20}$.

So, at the end, the Mystery of Christ will be fulfilled when the created nature starts to exist as beginningless, which does not mean anything else but that it will exist as the uncreated. To support the view that this is not only one of the possibilities of interpretation, we can turn our attention to a very explicit text of St. Gregory Palamas which directly refers to this thought of St. Maximus. In this text we find the direct identification of beginninglessness and the uncreatednesss. St. Gregory says:

But, as we have shown above, the saints clearly state that this adoption, actualised by faith, is enhypostatic. Nonetheless, our opponent affirms that the imitation of God, which he alone considers to be the thearchy and the deifying gift, is not enhypostatic. It is therefore something different from the deification which the Fathers possessed and knew. Yet the divine Maximus has not only taught that it is enhypostatic, but also that it is unoriginate (not only uncreated), indescribable and supratemporal. Those who attain it become thereby uncreated, unoriginate and indescribable, although in their own nature, they derive from nothingness ${ }^{21}$.

\section{Conclusion}

In the light of what these texts are about, how should we understand the, for Christian ontology, fundamental distinction between the

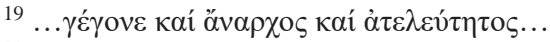

${ }^{20}$ Amb. 10, PG 91, 1144C; A. Louth, Maximus the Confessor, p. 116.

${ }^{21}$ Defensio Hesychastarum 3.1.31; critical edition: Grégoire PALAMAS, Défense des saints hésychastes, Introduction, texte critique, traduction et notes par Jean MEYENDORFF, Louvain, p. 617; English translation to which I refer: Gregory PALAMAS, The Triads, trans. Nicolas Gendle, Mahwah, NJ, Paulist Press, 86. 
uncreated and created reality?

Given the limitations of this paper, I will turn our attention to one aspect of St. Maximus' thought which, I believe, is conceptually of great importance for understanding and solving the problem of relation between the uncreated and created reality. I have in mind the concept of passivity $(\pi \alpha \dot{\theta} \theta \varsigma)$ which we can find too in the text that we are directly dealing with $^{22}$.

The concept of passivity plays an important role in St Maximus's theoretical explanation of the mystical experience of deification ${ }^{23}$. However, as the concept of deification is one of the key ideas in Maximus' ontology, it is natural that the concept of passivity may be inevitable in dealing with cosmological issues too. Substantial interdependence between cosmology and eschatology may be considered as a clear aspect of origenistic heritage in St. Maximus' thought.

In this sense, the end or goal of the natural movement of the created reality is the supernatural state of deification. Both end (deification), and means by which it is possible to achieve it (movement), are in fact effected by the Creator, who is, at the same time, the only goal ${ }^{24}$. That is why the end, aim or goal, and means of achieving it may be considered, looking from the perspective of creature, as pathos, or passivity. In the same way as creature is passive regarding its deification, which is the fullness of its participation in the uncreated divine energies, so too can we say that it is passive regarding its own motion, since it is affected by its own motion, and that means its own existence. Since it is created, both the beginning and the end or aim of its existence are works of its Creator and are, looking from the perspective of creature, gifts from the outside. As St Maximus says:

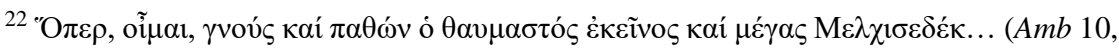
PG 91, 1137C); A. LouTH, Maximus the Confessor, p. 112.

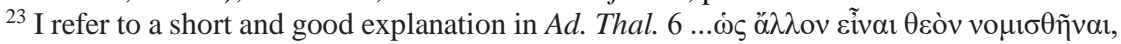

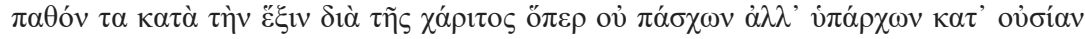

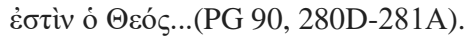

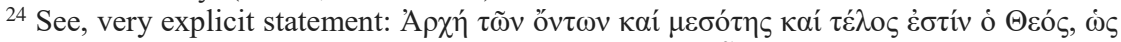

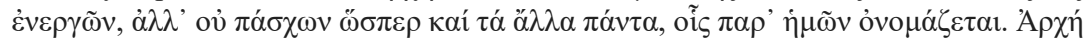

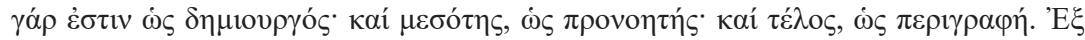

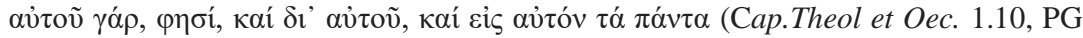
90, 1085D-1088A). 
To God only belongs to be the end, perfection and without passion, since he is unmovable, fullness and passionless, while creatures are moved towards the end which is without beginning and they can rest their activity by the unquantitativeness of the end, so that they will be affected by, without being or becoming by their essence, the absence of qualities [as their being]. Namely, it is clear that everything that has become and is created cannot be absolute. Therefore, we should accept with understanding that which has been said about the state of being affected [passivity]; namely, passivity [passion] does not mean that which is happening by change or corruptibility, but that which according to nature is coexistent with beings. Everything that has become is affected by movement, since it is not selfmovable and selfempowered... because our movement is from Him, as from the principle, and our way of moving too is defined by Him as the end ${ }^{25}$.

Now, I will point out to what I see as the logical consequences of these insights of St. Maximus. First, it can be said that there is continuity between the act of creation (moving) and deification (repose). The creature is passive regarding both its creation and deification which are consequences of God's uncreated activity. Moreover, there is no reason why we couldn't say that the very existence of creature is the uncreated activity or energy of God, or that the very existence of creature is uncreated. Not only supernatural future state, but also the current natural state of movement towards what is from our perspective future is reality of participation in that activity. The difference that can be established between the natural and supernatural is by no means a matter of essence, but rather the way of presence. Supernatural is the fullness of natural, a full presence of Creator in his creature ${ }^{26}$.

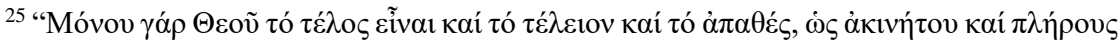

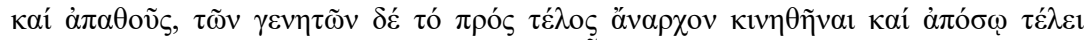

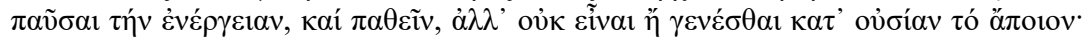

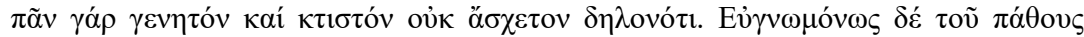

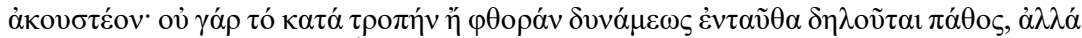

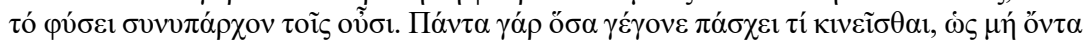

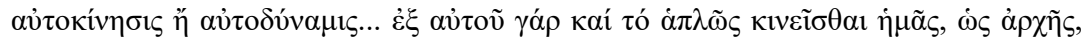

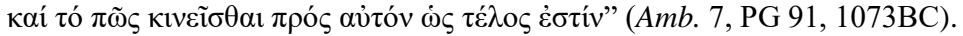

26 The eschatological concept of parousia ( $\pi \alpha \rho$ ov $\sigma i \alpha$, presence) is important in this respect. 
As a conclusion, I would say that, due to everything that has been mentioned, I believe that it is necessary to reexamine the meaning and boundaries that we set when we talk about an ontological difference between the created and the uncreated. Namely, such a determination is often understood as if it refers to the difference between the two orders of existence. I believe that it is necessary to make a correction; the ontological difference cannot refer to the difference between the two orders of existence, since the existence is by its nature unique; the true being is only the Divine Monad of the Holy Trinity. In that way, the ontological difference can be perceived only between being and nonbeing, existence and non-existence (both to be understood absolutely). The creature is ontologically different from God not because it exists in a different way, but because by itself it does not exist at all. Everything in the order of creatures that exists is a work of the uncreated divine activity and can be perceived as a form and sign of the uncreated presence of the only one truly existing reality.

\section{References}

1. Constas, Maximos, St. Maximos the Confessor: The Ambigua to John: Introduction to Ambiguum 10 (https://www.academia.edu/ 11023287/ Introduction_to_Maximos_the_Confessor_Ambigua_10.1-27, accessed April 29, 2017).

2. Louth, Andrew, Maximus the Confessor, London and New York, Universiy of Durham, Routledge, 1999.

3. Palamas, Grégoire, Défense des saints hésychastes, Introduction, texte critique, traduction et notes par Jean Meyendorff, Seconde édition, Louvain; Gregory PALAMAS, The Triads, trans. Nicolas Gendle, Mahwah, NJ, Paulist Press.

4. PLASS, Paul, "Transcendent Time in Maximus the Confessor", in The Thomist, no. 2/ 1980, p. 259-294.

5. SHERwOOD, Polycarp, "The Earlier Ambigua of S. Maximus the Confessor and his Refutation of Origenism", in Studia Anselmiana, XXXVI, Roma, 1955.

6. SHERWOOD, Polycarp, "Maximus and Origenism. APXH KAI TE $\Lambda \mathrm{O} \Sigma$ ", in Berichte zum XI. Internationalen Byzantinisten-Kongress, Munchen, 1958, Korreferate zu III, 1, Munchen, Beck, 1958, p. 1-26. 
7. БЕНЕВич, Г. И, “Об оппонентах преп. Максима в Трудностях $\kappa$ Иоанну (дополнение к исследованию Поликарпа Шервуда): Не только оригенизм", in: ур. Г. И. БЕНЕВИч, Преподобный Максим Исповедник: Полемика с оригенизмом и моноэнергизмом, Санкт Петербург, Издательство Олега Абышко, 2014, p. 593-613.

8. БЕНЕВич, Григорий В, “Логос Мелхиседека. Экзегеза и парадигма обожения у прп. Максима Исповедника”, in Вестник, по. 1/2011, p. 90-197. 